\title{
MANAGEMENT OF THRIPS AND POD BORERS USING CHEMICALS, BOTANICALS AND BIOPESTICIDES IN MUNGBEAN
}

\author{
K.N. Islam ${ }^{*}$, M.M.H. Khan ${ }^{2}$, M.A. Latif ${ }^{3}$, M.M. Uddin ${ }^{4}$ and M.M. Islam ${ }^{5}$ \\ ${ }^{* 1}$ RHRS, Bangladesh Agricultural Research Institute, Lebukhali, Patuakhali, Bangladesh \\ ${ }^{2}$ Department of Entomology, Patuakhali Science and Technology University \\ Dumki, Bangladesh \\ ${ }^{3}$ Department of Entomology, Sher-e-Bangla Agricultural University, Dhaka, Bangladesh \\ ${ }^{4}$ Department of Entomology, Bangladesh Agricultural University, Mymensingh, Bangladesh \\ ${ }^{5}$ Soil Conservation and Watershed management Centre, SRDI, Bandarban, Bangladesh
}

\begin{abstract}
The experiment was conducted to find out effective control measure against thrips and pod borers of mungbean by various means, including chemicals, botanicals and biopesticide. The mungbean variety, BARI Mung- 6 was grown in the field and six treatments viz., $T_{1}$ [Azadirachtin (Bioneem plus 1EC)], $\mathrm{T}_{2}$ [Bacillus thuringiensis (Bt. powder)], $\mathrm{T}_{3}$ [Spinosad (Tracer 45SC)], $\mathrm{T}_{4}$ [Chlorpyrifos + Cypermethrin (Nitro 505EC)], $T_{5}$ [Thiamethoxam + Chlorantraniliprole (Voliam flexi 300SC)] and $T_{0}$ [Untreated control (water spray)] were set in randomized complete block design (RCBD) with three replications. The insecticidal treatment options showed significantly different performance against thrips (Megalurothrips distalis), gram pod borer (Helicoverpa armigera) and legume pod borer (Maruca vitrata) on mungbean. The lowest population of thrips, gram pod borer and legume pod borer was found in Voliam flexi 300SC treated plot which showed maximum percent reduction of these pests. The lowest percent pod infestation by pod borers observed by the same treatment. Bioneem plus showed the intermediate results considering all the parameters. The maximum yield $\left(1254.50 \mathrm{~kg} \mathrm{ha}^{-1}\right)$ and the highest marginal benefit cost ratio (MBCR) (6.68) were obtained from Voliam flexi 300SC. Considering effectiveness and marginal benefit cost ratio, Voliam flexi 300SC was more effective among treatments for controlling thrips and pod borers of mungbean followed by Nitro 505EC.
\end{abstract}

Keywords: gram pod borer, legume pod borer, mungbean, thrips,

\footnotetext{
*Corresponding author: kbd_nazrul@yahoo.com
} 


\section{INTRODUCTION}

Mungbean (Vigna radiata L. Wilczek) belonging to the family leguminosae is an ancient and widely used pulse crop. It is one of the most important pulse crops of Bangladesh. This crop is known as green gram, golden gram, sonamung, mungbean but commonly as 'Moog' in Bangladesh. It contributes only about $11.53 \%$ of the total pulse production in Bangladesh and ranks fifth among the pulse crops (BARC, 2013). It is a rich source of protein and several essential micronutrients like as calcium, iron, and $\beta$-Carotene. Mungbean seed contains 52\% carbohydrate, 26\% protein, $10 \%$ moisture, 4\% minerals and 3\% vitamins (Kaul, 1982). It also contains amino acid lysine, which is generally deficient in food grains (Elias et al., 1986). According to FAO (2013) recommendation, a minimum intake of pulse by a human should be 80 $\mathrm{g} /$ day, whereas it is only $7.92 \mathrm{~g}$ in Bangladesh (BBS, 2014). Additionally this leguminous plant fixes atmospheric nitrogen $\left(58-109 \mathrm{~kg} \mathrm{ha}^{-1}\right)$ through symbiosis with a Rhizobium species into the soil. Apart from these, addition of organic matter to the soil is important factors in maintaining soil fertility (Zapata et al., 1987). Some of the constraints limiting mungbean production include absence of improved varieties, low yield potential of the crop, lack of research and extension focus, attacking of insect pests, low domestic market and inconsistency of the crop's performance.

The reasons of low yield are numerous but yield losses due to insect pest complex are distinct one. Insect pests attack is considered as the most important one limiting mungbean production. More than twelve species of insect pests are found to infest mungbean in Bangladesh (Anonymous, 1998), among them stemfly (Lal, 1985; Rahman, 1987), aphid and whitefly (Rahman et al., 1981), thrips (Rahman et al., 1981; Hossain et al., 2004), hairy caterpillar (Rahman et al., 1981) and pod borers (Rahman et al., 1981, Hossain et al., 2004) are considered major ones. Both nymph and adults of thrips (Megalurothrips distalis Karny) nourish on pollen and scratch flower parts by sucking the plant sap causing flower drop resulted in less pod formation. Severe infestation of thrips resulted flower shedding causing significant yield loss (Lal, 1985). Heavy infestation of pod borer occurs at flowering and pod filling stages. Pod borer damages flowers, flower buds and developing or mature pods (Poehlman, 1991). In the field, gram pod borer (Helicoverpa armigera) and legume pod borer (Maruca vitrata) is considered to be major insect pests in Bangladesh. The larvae bore into the young pods, remain there and feed on the seeds inside. It was reported that the yield reduction ranged from $30 \%$ to $70 \%$ due to thrips attack and 30\% to $40 \%$ by pod borer in Bangladesh (Afzal et al., 2004).

Though many options are available for the management of these insect pests, Bangladeshi farmers use different synthetic chemicals against different insect pests because of their quick knock down effect with or without knowing the bad effects of these chemicals. Information regarding insecticidal management practices selecting appropriate insecticides with proper doses in mungbean is not available. However, with the advent of high yielding and short duration varieties and increased market 
value of mungbean, farmers become interested on the cultivation of mungbean adopting proper pest management measures. Keeping this in view, the present study was carried out to evaluate the effectiveness of chemicals, botanicals and biopesticides against thrips and pod borers of mungbean.

\section{MATERIALS AND METHODS}

The experiment was conducted at the Agricultural Farm of Patuakhali Science and Technology University (PSTU), Dumki, Bangladesh during January to April 2017. The experiment was laid out in Randomized Complete Block Design with 3 replications. The unit plot size was $4 \mathrm{~m}$ x $2.5 \mathrm{~m}$ with a distance of $1 \mathrm{~m}$ between the plots and $1.5 \mathrm{~m}$ between the replications. BARI Mung- 6 was used as experimental material and was sown on 24 January at the rate of $30 \mathrm{~kg} \mathrm{ha}^{-1}$ (BARI, 2011) in rows maintaining spacing $(30 \mathrm{~cm} \times 10 \mathrm{~cm})$ for mungbean cultivation. The fertilizers were applied as per fertilizers recommendation guide (BARI, 2011). Urea, triple super phosphate (TSP) and muriate of potash (MoP) were applied in the field uniformly @ 50,85 and $35 \mathrm{~kg} \mathrm{ha}^{-1}$, respectively during the final land preparation. All intercultural operations (thinning out, gap filling, weeding, irrigation and drainage) were done as and when necessary to ensure normal growth and development of crops.

The experiment comprised five treatments of various insecticides and one untreated control. The treatments of the experiment were assigned as follows: (1) $\mathrm{T}_{1}=$ Azadirachtin (Bioneem plus 1EC) @ $1 \mathrm{ml} \mathrm{l}^{-1}$ of water; (2) $\mathrm{T}_{2}=$ Bacillus thuringiensis (Bt. powder) @ $1 \mathrm{~g} \mathrm{l}^{-1}$ of water; (3) $\mathrm{T}_{3}=$ Spinosad (Tracer 45SC) @ $0.3 \mathrm{ml} \mathrm{l}^{-1}$ of water; (4) $\mathrm{T}_{4}=$ Chlorpyrifos + Cypermethrin (Nitro 505EC) @ $1 \mathrm{ml} \mathrm{l}^{-1}$ of water; (5) $\mathrm{T}_{5}=$ Thiamethoxam + Chlorantraniliprole (Voliam flexi 300SC) @ $0.5 \mathrm{ml} \mathrm{l}^{-1}$ of water; (6) $\mathrm{T}_{0}=$ Untreated control (water spray @ $5001 \mathrm{ha}^{-1}$ ). The spray solutions at the pre-fixed concentration of the respective treatments were prepared in Knapsack sprayer by mixing with water as required just before spraying. The volume of spray in various treatments was as per the treatment design and water was sprayed on untreated control plot. The spray solutions were sprayed, at flowering stage (35 DAS) and at podding stage (42 DAS). The spraying was always done in the afternoon to avoid bright sunlight. The spray was done uniformly to obtain complete coverage of whole plants. Caution was taken to avoid any drift of the spray mixture to the adjacent plots at the time of the spray.

The data were recorded from incidence of thrips, gram pod borer and legume pod borer during different growth stages of the crop. Number of thrips, gram pod borer and legume pod borer was recorded at flowering stage and podding stage. The data on the population of thrips, gram pod borer and legume pod borer were collected before and after 1 day of spray application from each unit plot. Thrips population was assessed from 10 opened flowers which were randomly collected from two rows of each side of the plot avoiding border and central four rows. The collected flowers were immediately opened on the white paper and counted the thrips. The selected $1 \mathrm{~m}^{2}(1 \mathrm{~m} \times 1 \mathrm{~m})$ area of the center of each unit plot was kept undisturbed for recording 
yield data. Grains were recorded from $1 \mathrm{~m}^{2}$ area per plot wise and the yields were expressed in $\mathrm{kg} \mathrm{ha}^{-1}$.

For collecting data on the percentage of pod borer infested pods, the number of infested pods and the total number of pods from randomly selected 10 plants from each unit plot were counted at ripening stage and recorded. The following formula was used for taking the infestation percentage:

$$
\% \text { Pod infestation }=\frac{\text { Total number of infested pods }}{\text { Total number of pods }}-100
$$

Gross return (GR): The yield in terms of money that was measured by multiplying the total yield by the unit price of mungbean (Tk. $60 \mathrm{~kg}^{-1}$ ).

Net return (NR): The net return was calculated by subtracting treatment wise management cost from gross return.

Adjusted net return (ANR): The ANR was determined by subtracting the net return for a particular treatment from the net return with control plot.

Finally, the marginal benefit cost ratio (MBCR) for each treatment was calculated by using the following formula described by Elias and Karim (1984):

Adjusted net return

Marginal Benefit Cost Ratio $(\mathrm{MBCR})=\frac{\text { Adjul management cost }}{\text { Total }}$

\section{Statistical analysis}

The collected data was statistically analyzed through the analysis of variance (ANOVA) using WASP 1.0 package. The population data were transformed to square root $(\sqrt{ } x+0.5)$ values. Means were separated by critical difference $(\mathrm{CD})$ values at $5 \%$ level of significance.

\section{RESULTS AND DISCUSSION}

Efficacy of treatments on the incidence of thrips population at different growth stages

The results are mean comparison of the data, regarding the treatment effect on thrips (Megalurothrips distalis) population and percent reduction, at different growth stages (flowering stage and podding stage). The treatments also showed significant influence on the incidence of thrips (Table 1).

The lowest number of thrips (1.26 plot $^{-1}$ at flowering and 1.26 plot $^{-1}$ at podding stage) was observed in $\mathrm{T}_{5}$ [Thiamethoxam + Chlorantraniliprole (Voliam flexi 300SC)] treated plot followed by $\mathrm{T}_{4}$ [Chlorpyrifos + Cypermethrin (Nitro 505EC)] treated plot having significant difference between them. The highest number of thrips $\left(2.33 \mathrm{plot}^{-1}\right.$ at flowering and $2.08 \mathrm{plot}^{-1}$ at podding stage) was found in $\mathrm{T}_{0}$ [Untreated control] plot 
which was significantly higher than all other treated plots. The results of the present study reveal that all the insecticides significantly reduced thrips population infesting mungbean. However $\mathrm{T}_{5}$ [Thiamethoxam + Chlorantraniliprole (Voliam flexi 300SC)] was the most effective against thrips and $\mathrm{T}_{4}$ [Chlorpyrifos + Cypermethrin (Nitro 505EC)] was the second most effective treatment but $\mathrm{T}_{3}$ [Spinosad (Tracer 45SC)] was less effective. These results were in agreement with that of Hossain et al. (2004) who reported that schedule spraying of insecticides (Azodrin 40WSC, Cymbush 10EC, Nogos 100EC and Dimecron 100SCW) application reduced population of thrips on mungbean. Treatment $\mathrm{T}_{2}$ [Bacillus thuringiensis (Bt. powder)] and $\mathrm{T}_{1}$ [Azadirachtin (Bioneem plus 1EC)] was poorly effective against thrips infesting mungbean in field condition. Mumutaj (2014) also reported poor effectiveness of neem oil against population of thrips on mungbean.

Table 1. Efficacy of treatments on the incidence of thrips population at different growth stages in mungbean

\begin{tabular}{|c|c|c|c|c|c|c|}
\hline \multirow{3}{*}{ Treatments } & \multicolumn{3}{|c|}{ Flowering stage } & \multicolumn{3}{|c|}{ Podding stage } \\
\hline & \multicolumn{2}{|c|}{$\begin{array}{l}\text { No. of thrips/10 open } \\
\text { flowers }\end{array}$} & \multirow{2}{*}{$\begin{array}{c}\text { Reduction of } \\
\text { thrips } \\
\text { population after } \\
1 \text { day of spray } \\
(\%)\end{array}$} & \multicolumn{2}{|c|}{$\begin{array}{c}\text { No. of thrips/10 open } \\
\text { flowers }\end{array}$} & \multirow{2}{*}{$\begin{array}{l}\text { Reduction of thrips } \\
\text { population after } 1 \text { day } \\
\text { of spray }(\%)\end{array}$} \\
\hline & $\begin{array}{l}\text { Before } \\
\text { spray }\end{array}$ & $\begin{array}{c}\text { After } 1 \text { day } \\
\text { of spray }\end{array}$ & & $\begin{array}{c}\text { Before } \\
\text { spray }\end{array}$ & $\begin{array}{c}\text { After } 1 \text { day } \\
\text { of spray }\end{array}$ & \\
\hline $\mathrm{T}_{1}$ & $3.41 \mathrm{a}$ & $1.80 \mathrm{~b}$ & 47.21 & $3.20 \mathrm{bc}$ & $1.70 \mathrm{bc}$ & 46.88 \\
\hline $\mathrm{T}_{2}$ & $3.34 \mathrm{ab}$ & $1.63 \mathrm{~b}$ & 51.20 & $3.51 \mathrm{ab}$ & $1.74 \mathrm{ab}$ & 50.43 \\
\hline $\mathrm{T}_{3}$ & $3.23 \mathrm{abc}$ & $1.55 \mathrm{bc}$ & 52.01 & $3.10 \mathrm{c}$ & $1.43 \mathrm{bcd}$ & 53.87 \\
\hline $\mathrm{T}_{4}$ & $2.86 \mathrm{c}$ & $1.29 \mathrm{~cd}$ & 54.90 & $2.76 \mathrm{~d}$ & $1.26 \mathrm{~d}$ & 54.35 \\
\hline $\mathrm{T}_{5}$ & $2.97 \mathrm{bc}$ & $1.26 \mathrm{~d}$ & 57.58 & $3.04 \mathrm{~cd}$ & $1.26 \mathrm{~d}$ & 58.55 \\
\hline $\mathrm{T}_{0}$ & $3.51 \mathrm{a}$ & $2.33 \mathrm{a}$ & 33.62 & $3.55 \mathrm{a}$ & $2.08 \mathrm{a}$ & 41.41 \\
\hline $\mathrm{CV}(\%)$ & 6.44 & 8.97 & - & 5.69 & 12.33 & - \\
\hline $\mathrm{CD}(0.05)$ & 0.38 & 0.27 & - & 0.33 & 0.36 & - \\
\hline
\end{tabular}

In a column means having dissimilar letter(s) differ significantly as per 0.05 level of probability. $\mathrm{CV}=$ Coefficient of Variation, $\mathrm{CD}=$ Critical Difference.

$\mathrm{T}_{1}=$ Azadirachtin (Bioneem plus 1EC) @ $1 \mathrm{ml} \mathrm{l}^{-1}$ of water; $\mathrm{T}_{2}=$ Bacillus thuringiensis (Bt. powder) @ $1 \mathrm{~g} \mathrm{l}^{-1}$ of water; $\mathrm{T}_{3}=$ Spinosad $($ Tracer $45 \mathrm{SC}) @ 0.3 \mathrm{ml} \mathrm{l}^{-1}$ of water; $\mathrm{T}_{4}=$ Chlorpyrifos + Cypermethrin (Nitro 505EC) @ $1 \mathrm{ml} \mathrm{l}^{-1}$ of water; $\mathrm{T}_{5}=$ Thiamethoxam + Chlorantraniliprole (Voliam flexi 300SC) @ $0.5 \mathrm{ml} \mathrm{l}^{-1}$ of water; $\mathrm{T}_{0}=$ Untreated control (water spray) @ $5001 \mathrm{ha}^{-1}$.

\section{Percentage reduction of thrips population after spraying over control at different growth stages}

The highest reduction (45.92\%) of thrips over control was noticed in $\mathrm{T}_{5}$ followed by $\mathrm{T}_{4}(44.63 \%), \mathrm{T}_{3}(33.48 \%), \mathrm{T}_{2}(30.04 \%)$ and $\mathrm{T}_{1}(22.75 \%)$ at flowering stage (35 DAS). Thus the order of performances of treatments in descending of efficiency was $\mathrm{T}_{5}>\mathrm{T}_{4}>\mathrm{T}_{3}>\mathrm{T}_{2}>\mathrm{T}_{1}>\mathrm{T}_{0}$ (Fig. 1). 


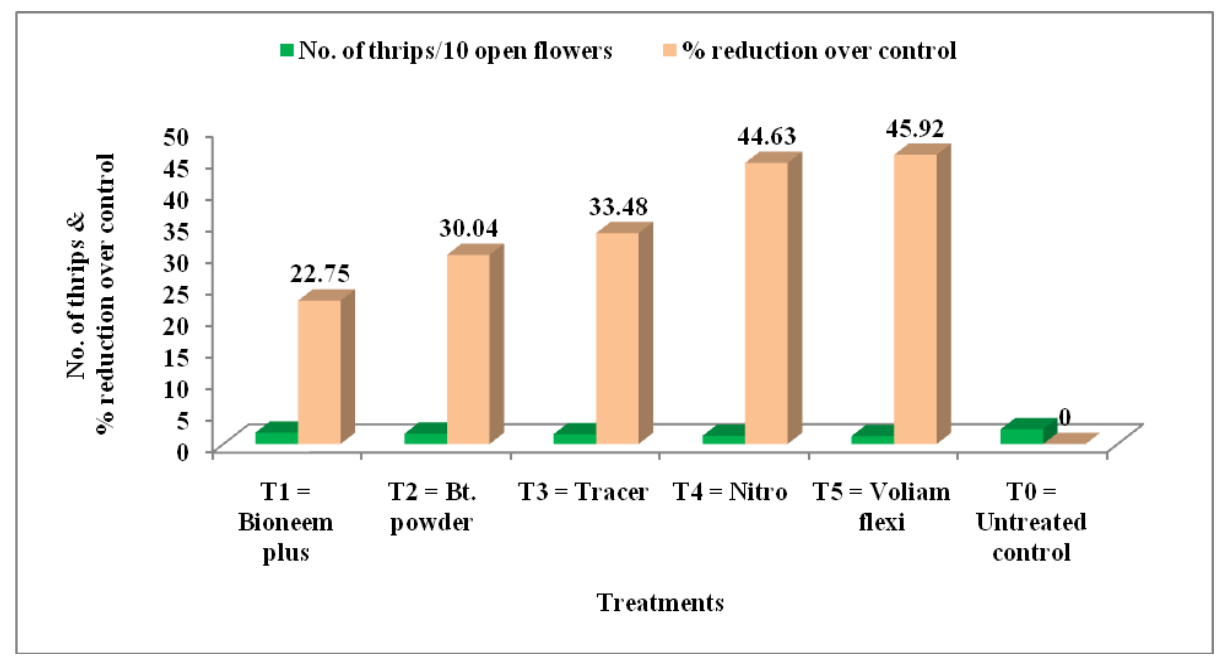

Figure 1. Population of thrips/10 open flowers after 1 day of spray and $\%$ reduction over control under treatments at flowering stage

The highest reduction (39.42\%) of thrips over control was noticed in $\mathrm{T}_{5}$ which was statistically identical to $\mathrm{T}_{4}$ and followed by $\mathrm{T}_{3}(31.25 \%), \mathrm{T}_{1}(18.27 \%)$ and $\mathrm{T}_{2}$ $(16.35 \%)$ at podding stage (42 DAS). Thus the order of performances of treatments in descending of efficiency was $\mathrm{T}_{5}>\mathrm{T}_{4}>\mathrm{T}_{3}>\mathrm{T}_{1}>\mathrm{T}_{2}>\mathrm{T}_{0}$ (Fig. 2).

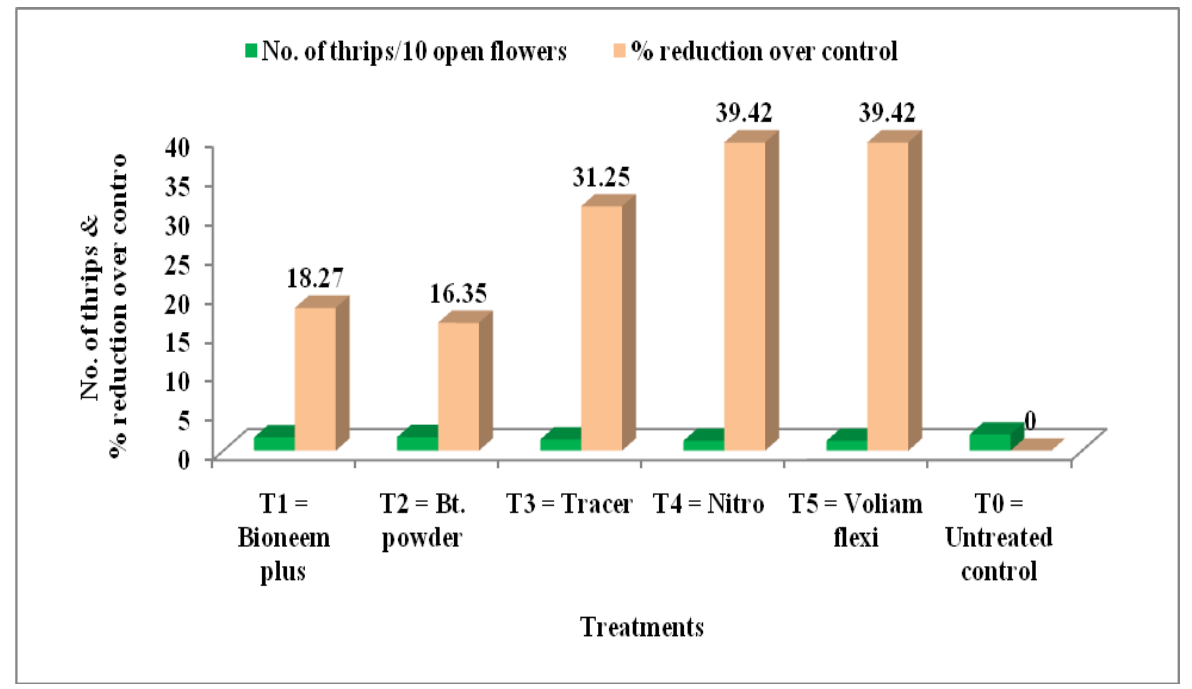

Figure 2. Population of thrips/10 open flowers after 1 day of spray and $\%$ reduction over control under treatments at podding stage 


\section{Efficacy of treatments on the incidence of pod borers' population at different growth stages}

The results are mean comparison of the data, regarding the treatment effect on gram pod borer (Helicoverpa armigera) and legume pod borer (Maruca vitrata) and percent reduction at different growth stages (flowering stage and podding stage). The treatments also showed significant influence on the incidence of gram pod borer (Table 2) and legume pod borer (Table 3).

Table 2. Efficacy of treatments on the incidence of gram pod borer population at different growth stages in mungbean

\begin{tabular}{|c|c|c|c|c|c|c|}
\hline \multirow{3}{*}{$\begin{array}{l}\text { Treatm } \\
\text { ents }\end{array}$} & \multicolumn{3}{|c|}{ Flowering stage } & \multicolumn{3}{|c|}{ Podding stage } \\
\hline & \multicolumn{2}{|c|}{$\begin{array}{l}\text { No. of gram pod } \\
\text { borer/plot }\end{array}$} & \multirow{2}{*}{$\begin{array}{c}\text { Reduction of } \\
\text { gram pod borer } \\
\text { population after } 1 \\
\text { day of spray }(\%)\end{array}$} & \multicolumn{2}{|c|}{$\begin{array}{l}\text { No. of gram pod borer } \\
\text { /plot }\end{array}$} & \multirow{2}{*}{$\begin{array}{c}\text { Reduction of gram } \\
\text { pod borer } \\
\text { population after 1 } \\
\text { day of spray (\%) }\end{array}$} \\
\hline & $\begin{array}{l}\text { Before } \\
\text { spray }\end{array}$ & $\begin{array}{c}\text { After } 1 \\
\text { day of } \\
\text { spray }\end{array}$ & & $\begin{array}{l}\text { Before } \\
\text { spray }\end{array}$ & $\begin{array}{l}\text { After } 1 \text { day } \\
\text { of spray }\end{array}$ & \\
\hline $\mathrm{T}_{1}$ & $1.77 \mathrm{c}$ & $0.88 \mathrm{~b}$ & 50.28 & $2.33 \mathrm{ab}$ & $1.10 \mathrm{~b}$ & 52.79 \\
\hline $\mathrm{T}_{2}$ & $2.03 \mathrm{c}$ & $1.05 \mathrm{~b}$ & 48.28 & $2.03 \mathrm{bc}$ & $1.05 \mathrm{~b}$ & 48.28 \\
\hline $\mathrm{T}_{3}$ & $2.85 \mathrm{ab}$ & $1.34 \mathrm{~b}$ & 52.98 & $2.26 \mathrm{ab}$ & $1.05 \mathrm{~b}$ & 53.54 \\
\hline $\mathrm{T}_{4}$ & $2.61 \mathrm{~b}$ & $1.17 \mathrm{~b}$ & 55.17 & $2.00 \mathrm{bc}$ & $0.88 \mathrm{~b}$ & 56.00 \\
\hline $\mathrm{T}_{5}$ & $2.67 \mathrm{~b}$ & $0.88 \mathrm{~b}$ & 67.04 & $1.68 \mathrm{c}$ & $0.71 \mathrm{~b}$ & 57.74 \\
\hline $\mathrm{T}_{0}$ & $3.13 \mathrm{a}$ & $1.93 \mathrm{a}$ & 38.34 & $2.78 \mathrm{a}$ & $1.68 \mathrm{a}$ & 39.57 \\
\hline $\begin{array}{l}\mathrm{CV} \\
(\%)\end{array}$ & 9.21 & 26.37 & - & 14.60 & 24.72 & - \\
\hline $\begin{array}{l}\mathrm{CD} \\
(0.05)\end{array}$ & 0.42 & 0.59 & - & 0.58 & 0.48 & - \\
\hline
\end{tabular}

In a column means having dissimilar letter(s) differ significantly as per 0.05 level of probability. $\mathrm{CV}=$ Coefficient of Variation, CD = Critical Difference.

$\mathrm{T}_{1}=$ Azadirachtin (Bioneem plus 1EC) @ $1 \mathrm{ml} \mathrm{l}^{-1}$ of water; $\mathrm{T}_{2}=$ Bacillus thuringiensis (Bt. powder) @ $1 \mathrm{~g} \mathrm{l}^{-1}$ of water; $\mathrm{T}_{3}=$ Spinosad (Tracer $45 \mathrm{SC}$ ) @ $0.3 \mathrm{ml} \mathrm{l}^{-1}$ of water; $\mathrm{T}_{4}=$ Chlorpyrifos + Cypermethrin (Nitro 505EC) @ $1 \mathrm{ml} \mathrm{l}^{-1}$ of water; $\mathrm{T}_{5}=$ Thiamethoxam + Chlorantraniliprole (Voliam flexi 300SC) @ $0.5 \mathrm{ml} \mathrm{l}^{-1}$ of water; $\mathrm{T}_{0}=$ Untreated control (water spray) @ $5001 \mathrm{ha}^{-1}$. 
Table 3. Efficacy of treatments on the incidence of legume pod borer population at different growth stages in mungbean

\begin{tabular}{|c|c|c|c|c|c|c|}
\hline \multirow{3}{*}{ Treatments } & \multicolumn{3}{|c|}{ Flowering stage } & \multicolumn{3}{|c|}{ Podding stage } \\
\hline & \multicolumn{2}{|c|}{$\begin{array}{l}\text { No. of legume pod } \\
\text { borer/plot }\end{array}$} & \multirow{2}{*}{$\begin{array}{c}\text { Reduction of } \\
\text { legume pod borer } \\
\text { population after } 1 \\
\text { day of spray }(\%)\end{array}$} & \multicolumn{2}{|c|}{$\begin{array}{l}\text { No. of legume pod } \\
\text { borer/plot }\end{array}$} & \multirow{2}{*}{$\begin{array}{c}\text { Reduction of } \\
\text { legume pod borer } \\
\text { population after } 1 \\
\text { day of spray }(\%)\end{array}$} \\
\hline & Before spray & $\begin{array}{l}\text { After } 1 \text { day } \\
\text { of spray }\end{array}$ & & $\begin{array}{l}\text { Before } \\
\text { spray }\end{array}$ & $\begin{array}{l}\text { After } 1 \text { day } \\
\text { of spray }\end{array}$ & \\
\hline $\mathrm{T}_{1}$ & $2.41 \mathrm{ab}$ & $1.17 \mathrm{~b}$ & 51.45 & $2.41 \mathrm{abc}$ & $1.17 \mathrm{bc}$ & 51.45 \\
\hline $\mathrm{T}_{2}$ & $2.27 \mathrm{abc}$ & $1.17 \mathrm{~b}$ & 48.46 & $2.61 \mathrm{ab}$ & $1.46 \mathrm{ab}$ & 44.06 \\
\hline $\mathrm{T}_{3}$ & $2.32 \mathrm{abc}$ & $1.05 \mathrm{~b}$ & 54.74 & $2.58 \mathrm{ab}$ & $1.17 \mathrm{bc}$ & 54.65 \\
\hline $\mathrm{T}_{4}$ & $2.08 \mathrm{bc}$ & $0.88 \mathrm{~b}$ & 57.69 & $2.18 \mathrm{bc}$ & $1.05 \mathrm{bc}$ & 51.83 \\
\hline $\mathrm{T}_{5}$ & $1.76 \mathrm{c}$ & $0.71 \mathrm{~b}$ & 59.66 & $1.93 \mathrm{c}$ & $0.71 \mathrm{c}$ & 63.21 \\
\hline $\mathrm{T}_{0}$ & $2.79 \mathrm{a}$ & $1.86 \mathrm{a}$ & 33.33 & $2.97 \mathrm{a}$ & $2.04 \mathrm{a}$ & 31.31 \\
\hline $\mathrm{CV}(\%)$ & 13.90 & 30.38 & - & 13.37 & 25.41 & - \\
\hline $\mathrm{CD}(0.05)$ & 0.57 & 0.63 & - & 0.59 & 0.58 & - \\
\hline
\end{tabular}

In a column means having dissimilar letter(s) differ significantly as per 0.05 level of probability. $\mathrm{CV}=$ Coefficient of Variation, $\mathrm{CD}=$ Critical Difference.

$\mathrm{T}_{1}=$ Azadirachtin (Bioneem plus 1EC) @ $1 \mathrm{ml} \mathrm{l}^{-1}$ of water; $\mathrm{T}_{2}=$ Bacillus thuringiensis (Bt. powder) @ $1 \mathrm{~g} \mathrm{l}^{-1}$ of water; $\mathrm{T}_{3}=$ Spinosad (Tracer $45 \mathrm{SC}$ ) @ $0.3 \mathrm{ml} \mathrm{l}^{-1}$ of water; $\mathrm{T}_{4}=$ Chlorpyrifos + Cypermethrin (Nitro 505EC) @ $1 \mathrm{ml} \mathrm{l}^{-1}$ of water; $\mathrm{T}_{5}=$ Thiamethoxam + Chlorantraniliprole (Voliam flexi 300SC) @ $0.5 \mathrm{ml} \mathrm{l}^{-1}$ of water; $\mathrm{T}_{0}=$ Untreated control (water spray) @ $5001 \mathrm{ha}^{-1}$.

The lowest number of gram pod borer and legume pod borer $\left(0.88\right.$ and 0.71 plot $^{-1}$ at flowering and 0.71 and 0.71 plot $^{-1}$ at podding stage, respectively) was observed in $T_{5}$ [Thiamethoxam + Chlorantraniliprole (Voliam flexi 300SC)] treated plot followed by $\mathrm{T}_{4}$ [Chlorpyrifos + Cypermethrin (Nitro 505EC)] treated plot having significant difference between them. The highest number of gram pod borer and legume pod borer (1.93 and 1.86 plot $^{-1}$ at flowering and 1.68 and 2.04 plot $^{-1}$ at podding stage, respectively) was found in $\mathrm{T}_{0}$ [Untreated control] plot which was significantly higher than all other treated plots. The results of the present study revealed that all the insecticides significantly reduced gram pod borer and legume pod borer infesting mungbean. However, $\mathrm{T}_{5}$ [Thiamethoxam + Chlorantraniliprole (Voliam flexi 300SC)] was the most effective treatment against gram pod borer and legume pod borer while $\mathrm{T}_{4}$ [Chlorpyrifos + Cypermethrin (Nitro 505EC)] was the second most effective treatment. But treatments $\mathrm{T}_{3}$ [Spinosad (Tracer 45SC)], $\mathrm{T}_{1}$ [Azadirachtin (Bioneem plus 1EC)] and $\mathrm{T}_{2}$ [Bacillus thuringiensis (Bt. powder)] were less effective insecticides against gram pod borer and legume pod borer infesting mungbean in field condition. These results agreed with the report of Hossain et al. (2004) who reported that schedule spraying of insecticides (Azodrin 40WSC, Cymbush 10EC, Nogos 100EC and Dimecron 100SCW) application reduced population of pod borers on mungbean. 


\section{Percentage reduction of pod borers' population after spraying over control at different growth stages}

The highest reduction $(54.40 \%)$ of gram pod borer over control was noticed in $\mathrm{T}_{5}$ which was statistically identical to $\mathrm{T}_{1}$ and followed by $\mathrm{T}_{2}(45.60 \%), \mathrm{T}_{4}(39.38 \%)$ and $\mathrm{T}_{3}(30.57 \%)$ at flowering stage $(35 \mathrm{DAS})$. Thus the order of performances of treatments in descending of efficiency was $\mathrm{T}_{5}>\mathrm{T}_{1}>\mathrm{T}_{2}>\mathrm{T}_{4}>\mathrm{T}_{3}>\mathrm{T}_{0}$ (Fig. 3).

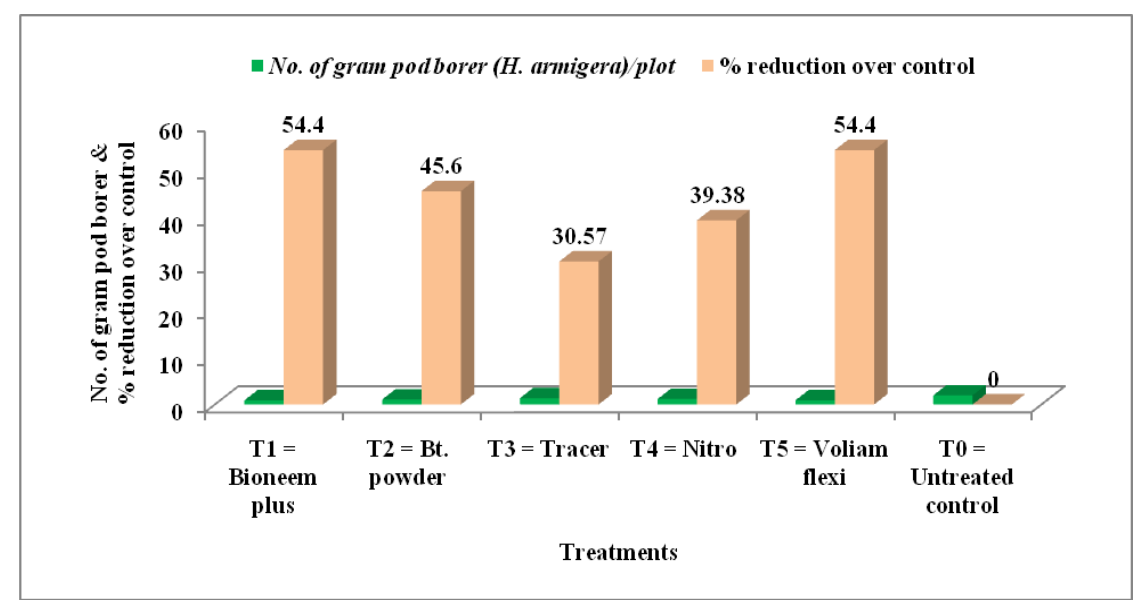

Figure 3. Population of gram pod borer/plot after 1 day of spray and \% reduction over control under treatments at flowering stage

The highest reduction (57.74\%) of gram pod borer over control was noticed in $\mathrm{T}_{5}$ followed by $\mathrm{T}_{4}(47.62 \%), \mathrm{T}_{3}(37.50 \%)$ and $\mathrm{T}_{2}(37.50 \%), \mathrm{T}_{1}(34.52 \%)$ at podding stage (42 DAS). Thus the order of performances of treatments in descending of efficiency was $\mathrm{T}_{5}>\mathrm{T}_{4}>\mathrm{T}_{3}>\mathrm{T}_{2}>\mathrm{T}_{1}>\mathrm{T}_{0}$ (Fig. 4).

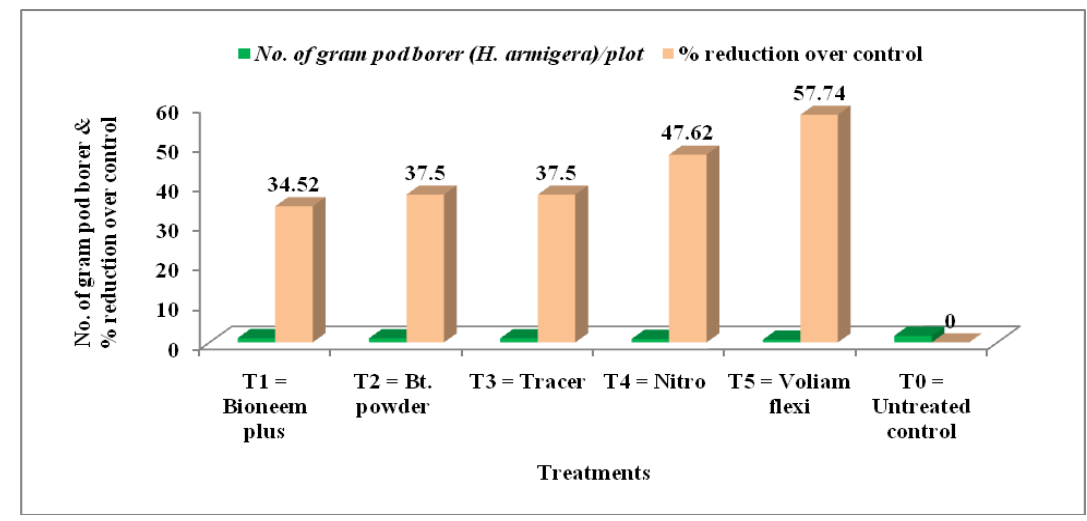

Figure 4. Population of gram pod borer/plot after 1 day of spray and \% reduction over control under treatments at podding stage

The highest reduction $(61.83 \%)$ of legume pod borer over control was noticed in $\mathrm{T}_{5}$ followed by $\mathrm{T}_{4}(52.69 \%), \mathrm{T}_{3}(43.55 \%), \mathrm{T}_{2}(37.10 \%)$ and $\mathrm{T}_{1}(37.10 \%)$ at flowering 
stage (35 DAS). Thus the order of performances of treatments in descending of efficiency was $\mathrm{T}_{5}>\mathrm{T}_{4}>\mathrm{T}_{3}>\mathrm{T}_{2}>\mathrm{T}_{1}>\mathrm{T}_{0}$ (Fig. 5).

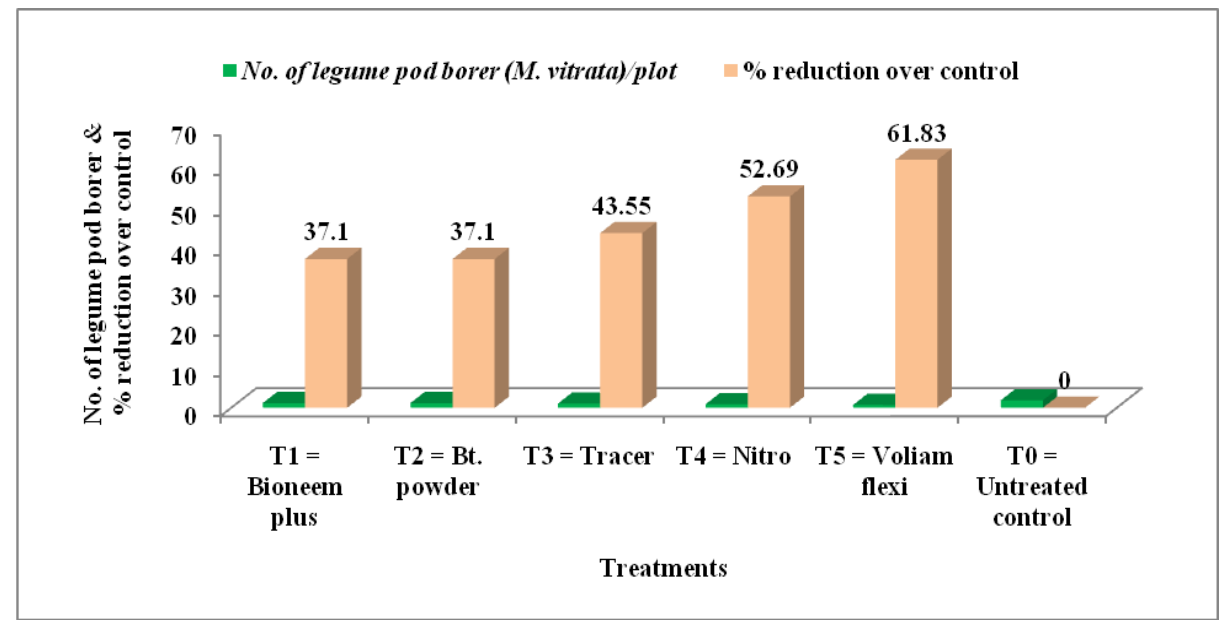

Figure 5. Population of legume pod borer/plot after 1 day of spray and $\%$ reduction over control under treatments at flowering stage

The highest reduction $(65.20 \%)$ of legume pod borer over control was noticed in $\mathrm{T}_{5}$ followed by $\mathrm{T}_{4}(48.53 \%), \mathrm{T}_{3}(42.65 \%)$ and $\mathrm{T}_{1}(42.65 \%), \mathrm{T}_{2}(28.43 \%)$ at podding stage (42 DAS). Thus the order of performances of treatments in descending of efficiency was $\mathrm{T}_{5}>\mathrm{T}_{4}>\mathrm{T}_{3}>\mathrm{T}_{1}>\mathrm{T}_{2}>\mathrm{T}_{0}$ (Fig. 6).

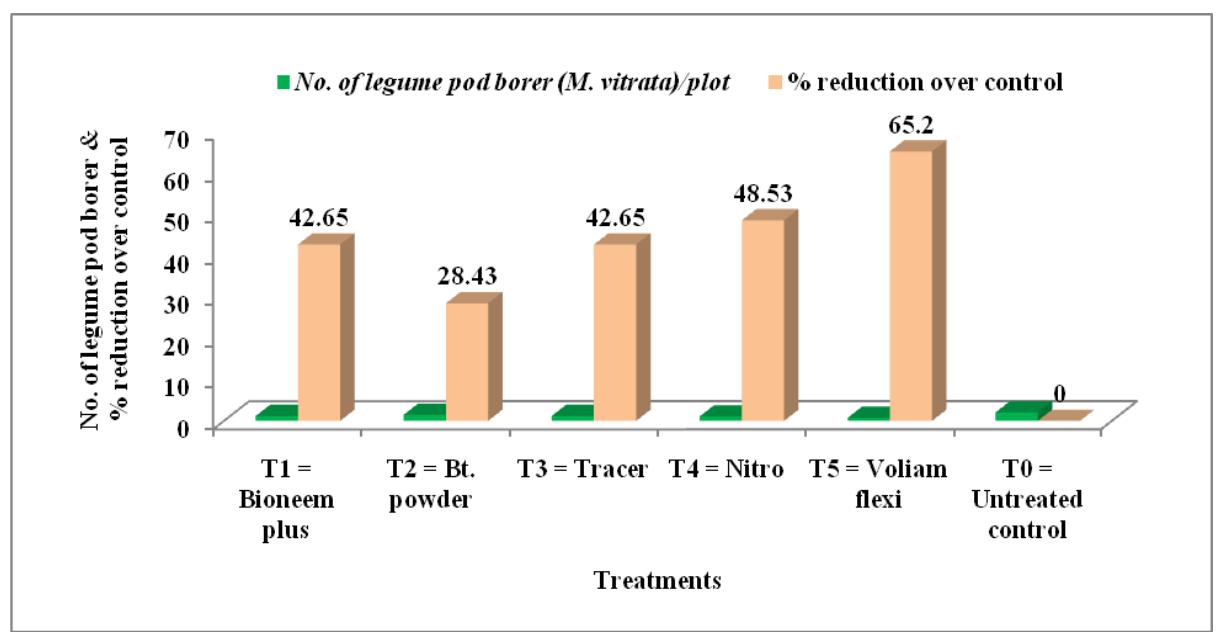

Figure 6. Population of legume pod borer/plot after 1 day of spray and \% reduction over control under treatments at podding stage 


\section{Percentage of pod infestation by pod borers at ripening stage}

The percentage of infested pods ranged from 2.33 to $18.53 \%$ (Table 4). The lowest pod infestation was observed $2.33 \%$ in $\mathrm{T}_{5}$ [Thiamethoxam + Chlorantraniliprole (Voliam flexi 300SC)] which was followed by $\mathrm{T}_{4}$ [Chlorpyrifos + Cypermethrin (Nitro 505EC)] (5.88\%), $\mathrm{T}_{3}$ [Spinosad (Tracer 45SC)] (7.48\%) and $\mathrm{T}_{1}$ [Azadirachtin (Bioneem plus 1EC)] (8.65\%). However, the highest percent pod infestation was $18.53 \%$ in $\mathrm{T}_{0}$ [Untreated control] followed by $\mathrm{T}_{2}$ [Bacillus thuringiensis (Bt. powder)] (13.47\%). The findings can be compared with the result of Anonymous (2014) who reported that Thiamethoxam + Chlorantraniliprole (Voliam flexi 300SC) treated plots had significantly lowest pod infestation.

Table 4. Efficacy of treatments on pod infestation by pod borers and Cost-benefit analysis of mungbean production

\begin{tabular}{|c|c|c|c|c|c|c|c|}
\hline Treatments & $\begin{array}{c}\text { Pod infestation by } \\
\text { Pod borers }(\%)\end{array}$ & $\begin{array}{c}\text { Cost of } \\
\text { management } \\
\text { (Tk.) }\end{array}$ & $\begin{array}{c}\text { Yield } \\
\left(\mathrm{kg} \mathrm{ha}^{-1}\right)\end{array}$ & $\begin{array}{l}\text { Gross } \\
\text { return } \\
(\mathrm{Tk} .)\end{array}$ & $\begin{array}{c}\text { Net } \\
\text { return } \\
(\mathrm{Tk} .)\end{array}$ & $\begin{array}{c}\text { Adjusted } \\
\text { net return } \\
(\mathrm{Tk} .)\end{array}$ & $\begin{array}{c}\text { Marginal } \\
\text { benefit cost } \\
\text { ratio }(\mathrm{MBCR})\end{array}$ \\
\hline $\mathrm{T}_{1}$ & $8.65 \mathrm{c}$ & 5400.00 & 1052.20 & 63132.00 & $\begin{array}{c}57732 . \\
00\end{array}$ & 10092.00 & 1.87 \\
\hline $\mathrm{T}_{2}$ & $13.47 \mathrm{~b}$ & 12450.00 & 1010.00 & 60600.00 & $\begin{array}{l}48150 . \\
00\end{array}$ & 510.00 & 0.04 \\
\hline $\mathrm{T}_{3}$ & $7.48 \mathrm{c}$ & 14056.50 & 1125.40 & 67524.50 & $\begin{array}{l}53467 . \\
50\end{array}$ & 5827.50 & 0.41 \\
\hline $\mathrm{T}_{4}$ & $5.88 \mathrm{c}$ & 3900.00 & 1176.70 & 70602.00 & $\begin{array}{c}66702 . \\
00\end{array}$ & 19062.00 & 4.89 \\
\hline $\mathrm{T}_{5}$ & $2.33 \mathrm{~d}$ & 3600.00 & 1254.50 & 75270.00 & $\begin{array}{c}71670 . \\
00\end{array}$ & 24030.00 & 6.68 \\
\hline $\mathrm{T}_{0}$ & $18.53 \mathrm{a}$ & - & 794.00 & 47640.00 & $\begin{array}{c}47640 . \\
00\end{array}$ & - & - \\
\hline $\mathrm{CV}(\%)$ & 17.14 & - & - & - & - & - & - \\
\hline $\mathrm{CD}(0.05)$ & 2.92 & - & - & - & - & - & - \\
\hline
\end{tabular}

In a column means having dissimilar letter(s) differ significantly as per 0.05 level of probability. $\mathrm{CV}=$ Coefficient of Variation, $\mathrm{CD}=$ Critical Difference.

$\mathrm{T}_{1}=$ Azadirachtin (Bioneem plus 1EC) @ $1 \mathrm{ml} \mathrm{l}^{-1}$ of water; $\mathrm{T}_{2}=$ Bacillus thuringiensis (Bt. powder) @ $1 \mathrm{~g} \mathrm{l}^{-1}$ of water; $\mathrm{T}_{3}=$ Spinosad (Tracer 45SC) @ $0.3 \mathrm{ml} \mathrm{l}^{-1}$ of water; $\mathrm{T}_{4}=$ Chlorpyrifos + Cypermethrin (Nitro 505EC) @ $1 \mathrm{ml} \mathrm{l}^{-1}$ of water; $\mathrm{T}_{5}=$ Thiamethoxam + Chlorantraniliprole (Voliam flexi 300SC) @ $0.5 \mathrm{ml} \mathrm{l}^{-1}$ of water; $\mathrm{T}_{0}=$ Untreated control (water spray) @ $5001 \mathrm{ha}^{-1}$.

For calculating marginal benefit cost ratio, the following prices were used: Bioneem plus 1EC @ Tk. 280/100 ml, Bt. powder @ Tk. 150/20 g, Tracer 45SC @ Tk. 200/7 ml, Nitro 505EC @ Tk. 90/50 ml and Voliam flexi 300SC @ Tk. 320/100 ml. Market price of mungbean seed @ Tk. 60/kg. Labor cost @ Tk. 400/man/8 hour 


\section{Yield and Marginal benefit cost ratio (MBCR)}

Various chemical, biological and botanical insecticides were used as pesticide to manage thrips and pod borers. $\mathrm{T}_{5}$ [Thiamethoxam + Chlorantraniliprole (Voliam flexi $300 \mathrm{SC})]$ showed the highest yield $\left(1254.50 \mathrm{~kg} \mathrm{ha}^{-1}\right)$ where the maximum reduction of thrips and pod borers population was found followed by $\mathrm{T}_{4}$ [Chlorpyrifos + Cypermethrin (Nitro 505EC)] (1176.70 kg ha ${ }^{-1}$ ) and $\mathrm{T}_{3}$ [Spinosad (Tracer 45SC)] $\left(1125.40 \mathrm{~kg} \mathrm{ha}^{-1}\right)$. On the other hand, the lowest yield $\left(794.00 \mathrm{~kg} \mathrm{ha}^{-1}\right)$ was found in $\mathrm{T}_{0}$ [Untreated control] plot because less reduction of thrips and pod borers was recorded on mungbean field (Table 4). These results agreed with the report of Anonymous (2014) who reported that seed yield $\left(\mathrm{kg} \mathrm{ha}^{-1}\right)$ varied significantly among different treatments which was similar to the findings of Hossain et al. (2004).

Cost-benefit analysis of treatments applied against thrips and pod borers on mungbean has been done. The net return and Marginal Benefit Cost Ratio (MBCR) varied depending on the costs of different chemicals used in treatments. The $\mathrm{T}_{0}$ [Untreated control] did not incur any pest management cost. For treatments, cost of insecticides was involved. Thus the highest marginal benefit cost ratio (6.68) was calculated in $\mathrm{T}_{5}$ [Thiamethoxam + Chlorantraniliprole (Voliam flexi 300SC)] followed by $\mathrm{T}_{4}$ [Chlorpyrifos + Cypermethrin (Nitro 505EC)] (4.89) and $\mathrm{T}_{1}$ [Azadirachtin (Bioneem plus 1EC)] (1.87). The minimum MBCR (0.04) was calculated in $\mathrm{T}_{2}$ [Bacillus thuringiensis (Bt. powder)] (Table 4). These results agreed with the report of Anonymous (2014) who reported that marginal benefit cost ratio varied among different treatments which was similar to the findings of Hossain et al. (2004).

\section{CONCLUSION}

The application of Thiamethoxam + Chlorantraniliprole (Voliam flexi 300SC) is the most profitable approach for the management of thrips and pod borers of mungbean followed by Chlorpyrifos + Cypermethrin (Nitro 505EC) for suppressing these insect pests.

\section{REFERENCES}

Afzal, M.A., Bakar, M.A., Hamid, A., Haque, M.M. and Akhtar, M.S. (2004). Mungbean in Bangladesh. Lentil, Blackgram and Mungbean Development Pilot Project, Pulses Research Center, BARI, Gazipur-1701. Publication no. 23. p.60

Anonymous. (2014). Annual Report 2013-2014. Division of Entomology. Bangladesh Agricultural Research Institute (BARI), Joydebpur, Gazipur, Bangladesh, pp.5-10

Anonymous. (1998). Mungbean cultivation in Bangladesh. Publication No. 17. Pulses Research Station, Bangladesh Agricultural Research Institute (BARI), Joydebpur, Gazipur, Bangladesh, p. 32

BARC. (2013). Hand Book of Agricultural Technology. Bangladesh Agricultural Research Council, Farmgate, Dhaka, Bangladesh, p.61 
BARI. (2011). Krishi Projukti Hatboi (Handbook on Agro-technology), $5^{\text {th }}$ edition Bangladesh Agricultural Research Institute, Gazipur, Bangladesh, pp.164-165

BBS. (2014). Yearbook of Agricultural Statistics. Bangladesh Bureau of Statistics, Statistics and Informatics Division (SID), Ministry of Planning, Govt. of the People's Republic of Bangladesh, Dhaka, p.156

Mumutaj, H. (2014). Management of mungbean thrips (Megalurothrips distalis) using chemical insecticides and neem oil. MS in Entomology thesis. Sher-e-Bangla Agricultural University, Dhaka, Bangladesh, p.27

Elias, S.M. and Karim, M.R. (1984). Application of partial budget technique on crop-ping system research at Chittagong. AER No. 10. Division of Agricultural Economics, BARI, Gazipur, Bangladesh, p.34

Elias, S.M., Hossain, M.S., Sikder, F.S., Ahmed, J. and Karim, R.M. (1986). Identification of constraints to pulse production with special reference to present farming systems. Annual Report of the Agricultural Economics Division, Bangladesh Agricultural Research Institute (BARI), Joydebpur, Gazipur, Bangladesh, p.1

FAO. (2013). (Food and Agriculture Organization). (2013): http://faostat.fao.org.

Hossain, M.A., Ferdous, J., Sarkar, M.A. and Rahman, M.A. (2004). Insecticidal management of thrips and pod borers in mungbean. Bangladesh Journal of Agricultural Research, 29(3): 347-356.

Kaul, A.K. (1982). Pulses in Bangladesh, BARC (Bangladesh Agricultural Research Council). Farmgate, Dhaka, Bangladesh, p.27

Lal, S.S. (1985). A review of insect pests of mungbean and their control in India. Tropical Pest Management, 31(2): 105-114., doi: 10.1080/09670878509370960.

Poehlman, J.M. (1991). The Mungbean. Oxford and IBH Publ. Co. Pvt. Ltd., New Delhi, Bombay and Calcutta, p.292

Rahman, M.M. (1987). Evaluation of sumithion as a component or an integrated pest management program to control insect pests of mungbean. Abstract or the Bangladesh Science Conference 12. Bangladesh Association for Advancement of Science. Section 1, 38-39.

Rahman, M.M., Mannan, M.A. and Islam, M.A. (1981). Pest survey of major summer and winter pulses in Bangladesh, In the Proceedings of the National Workshop on pulses. (eds.) A.K. Kaul, pp.265-273

WASP 1.0 package (ICAR - Central Coastal Agricultural Research Institute, Goa, Web Access Statistical Packages. http://icargoa.res.in/waspnew.html).

Zapata, F., Danso, F., Hardarson, G. and Fried, M. (1987). Nitrogen fixation and translocation in field-grown fababean. Agronomy Journal, 79: 505-509. doi:10.2134/agronj1987. $00021962007900030020 x$. 